\title{
Assessment of awareness regarding human papilloma virus vaccine among medical students: a knowledge attitude and practice study
}

\author{
Shetty Theertha S.*, Priya Kamath
}

Department of Obstetrics and Gynecology, AJ Institute of Medical sciences and Research centre, Mangalore, Karnataka, India

Received: 10 March 2019

Accepted: 02 April 2019

\section{*Correspondence:}

Dr. Shetty Theertha S,

E-mail: shettytheerthas@gmail.com

Copyright: () the author(s), publisher and licensee Medip Academy. This is an open-access article distributed under the terms of the Creative Commons Attribution Non-Commercial License, which permits unrestricted non-commercial use, distribution, and reproduction in any medium, provided the original work is properly cited.

\section{ABSTRACT}

Background: Assessment of knowledge and awareness regarding human papilloma virus and cervical cancer among medical students.

Methods: Questionnaire based prospective study of 200 III and IV year consenting medical students willing to be a part of the study. 25 questions were in the questionnaire and they were asked to tick in front of the answer which they felt was correct. 3 questions regarding demographic details were formulated. To assess knowledge, attitude and practice total of 10, 8 and 4 questions were formulated respectively. Score of $0,1,2$ and 3 were given to answers for statistical analysis.

Results: A 110 (55\%) belonged to III year and 90 (45\%) belonged to IV year. $112(56 \%)$ were females and 88 (44\%) were males. 180 (90\%) were aware regarding agent causing cervical cancer. $77.8 \%$ of IV MBBS and all students of III MBBS knew the etiology. 98\% knew the screening technique while 190 (95\%) knew that vaccine availability for cervical cancer. $60 \%$ knew that the infection was sexually transmitted, and majority knew it is not curable with antibiotics. $70 \%$ knew route of administration while most were unaware about age of administration. $91 \%$ had not taken the vaccine while $41.5 \%$ would if offered. $73 \%$ knew the vaccine is ineffective against other STD's and most agreed that vaccine should be in the national immunization schedule. $40 \%$ knew that men should be vaccinated while $79 \%$ would recommend it to others.

Conclusions: Primary prevention of cervical cancer with vaccination is a novel concept. Health professionals can play a role in propagating this practice. Syllabus in medical schools must emphasize on such topics.

Keywords: Attitude, Human papilloma virus, Knowledge, Practice, Prevention, Vaccine

\section{INTRODUCTION}

Cervical cancer happens to be $4^{\text {th }}$ most common cancer among women all around the world with an estimated 527,624 new cases and 265,672 deaths in 2012. ${ }^{1}$ Of these a total of 2,30,000 (85\%) deaths have been reported in developing countries with scant amenities to cope with the situation. ${ }^{2}$ India has a population of 365,71 million women above 15 years of age, who are at a risk of developing cervical cancer. ${ }^{3}$ Present numbers indicate approximately 132,000 new cases diagnosed and 74000 deaths occur every year in India amounting to around $1 / 3^{\text {rd }}$ of the cervical cancer deaths around the globe. ${ }^{3}$ Indian women have a $2.5 \%$ mounting lifetime risk and $1.4 \%$ risk of death from cervical cancer. The virus also causes condyloma (genital warts) through type 6 and 11 . In all sexes, most HPV infections do not give symptoms but sometimes they cause changes in the epithelium of 
the cervix, which can lead to cervical cancer. ${ }^{4}$ Most women are immune to eliminate HPV infection spontaneously; however the infection can persist in a small proportion of women and can cause precancerous changes in the cells. ${ }^{5}$

Majority of Indian women diagnosed with cervical cancer have never been assessed for the disease and approximately $70 \%$ of them report in advance stages owing to the lack of organized screening programmes for cervical cancer. ${ }^{5}$ Cervical cancer is amiable to prevention as it has a viral aetiology, treatable precancerous lesion and access to screening. Since, cervical cancer screening detects only precancerous and cancerous changes after they have occurred, HPV vaccination is primary prevention. ${ }^{6}$

Two vaccines, one quadrivalent Gardasil (against type $16,18,11,6)$ and one bivalent cervarix (against type 16 and 18) have been developed which are targeted to girls in age around 11 since the tests of the vaccine show higher antibody levels in that age group (WHO 2007) have been demonstrated to be safe in several clinical trials. ${ }^{4,6}$ Creating awareness and educating the masses will play a significant role in execution of this strategy since preventing cervical cancer with the help of a vaccine is a fairly recent concept. ${ }^{7}$

Today's medical students will serve the community in future. It is crucial that they should be aware of the advances as they serve an important role in spreading awareness among population. ${ }^{6}$ Therefore, the study is aimed to know the knowledge and awareness of the medical students regarding the aetiology of cervical cancer, vaccine availability, target population, side effects, dosage of vaccine and immunization schedule. ${ }^{6}$

The aims and objectives of the study was the assessment of the knowledge and awareness regarding Human papilloma virus and cervical cancer among medical students.

\section{METHODS}

Questionnaire based prospective study comprising of medical students in III and IV year of A.J. Institute of Medical Sciences who gave consent and were willing to be a part of the study. On obtaining ethical clearance from the Institutional ethics committee and consent from the medical students, they were briefed regarding the study and a detailed validated questionnaire was handed over to them to assess their knowledge and awareness regarding HPV, HPV vaccination and cervical cancer.

They were allowed to ask questions regarding their participation in the study. The right to withdraw from the study at any point was ensured. Consent was obtained from the participant separately in order to avoid personal identification. Thus, anonymity and confidentiality was ensured. Total of 25 questions were included in the questionnaire and the students were asked to tick in front of the answer which they felt was correct.3 questions regarding the demographic details were formulated. To assess knowledge, attitude and practice a total of 10, 8 and 4 questions were formulated for each parameter respectively. Score of $0,1,2$ and 3 were given to the answers obtained for the purpose of Statistical analysis. Questionnaires were collected and the statistical analysis of the data was done.

\section{Inclusion criteria}

- Medical students of III and IV year of A.J. Institute of Medical Sciences who are willing to participate in the study.

\section{Exclusion criteria}

- Students who did not give consent to participate in the study.

\section{Statistical analysis}

The data was analyzed using chi-square test. $\mathrm{P}$ value $<0.05$ was considered significant.

The data was also evaluated using Mann Whitney test and the $\mathrm{Z}$ value was calculated using SPSS software.

\section{RESULTS}

A total of 200 students participated in the study, out of which $110(55 \%)$ belonged to III year while $90(45 \%)$ belonged to IV year.

Table 1: Distribution as per sex.

\begin{tabular}{|lll|}
\hline Sex & Frequency & Percentage \\
\hline Female & 112 & 56.0 \\
\hline Male & 88 & 44.0 \\
\hline Total & 200 & 100.0 \\
\hline
\end{tabular}

$170(85 \%)$ were in the age group of 20-22 years while 30 (15\%) were 23 and above, majority of the participants were females i.e. $112(56 \%)$ while $88(44 \%)$ were males (Table 1 and 2).

Table 2: Distribution as per-semester.

\begin{tabular}{|l|l|l|}
\hline Semester & Frequency & Percentage \\
\hline III MBBS & 90 & 55.0 \\
\hline IV MBBS & 110 & 45.0 \\
\hline Total & 200 & 100.0 \\
\hline
\end{tabular}

Majority of them i.e. 180 (90\%) were aware regarding the causative agent of cervical cancer.77.8\% of IV MBBS while all the students of III MBBS were aware regarding the etiology of cervical cancer. 
A $98 \%$ were aware regarding the screening technique for cervical cancer. Majority of them i.e. 190 (95\%) were aware regarding the availability of a vaccine for cervical cancer.

Table 3: Knowledge.

\begin{tabular}{|c|c|c|c|c|c|c|c|c|c|}
\hline & Semester & $\mathbf{N}$ & Mean & SD & $\begin{array}{l}\text { Median } \\
\text { (QR) }\end{array}$ & $\begin{array}{l}\text { Level of } \\
\text { knowledge (\%) }\end{array}$ & $\begin{array}{l}\text { Gap } \\
(\%)\end{array}$ & $\begin{array}{l}\text { Mann Whitney } \\
\text { Z value }\end{array}$ & $\begin{array}{l}P \text { - } \\
\text { value }\end{array}$ \\
\hline \multirow{2}{*}{ Etiology } & IV MBBS & 90 & 0.78 & 0.418 & $1(1-1)$ & 77.78 & 22.22 & 5.20 & \multirow{2}{*}{$\begin{array}{l}0.000 \\
\mathrm{HS}\end{array}$} \\
\hline & III MBBS & 110 & 1.00 & 0.000 & $1(1-1)$ & 100.00 & & & \\
\hline \multirow{2}{*}{ Risk factors } & IV MBBS & 90 & 1.86 & 1.223 & $2(0.75-3)$ & 37.11 & 11.66 & 4.10 & \multirow{2}{*}{$\begin{array}{l}0.000 \\
\mathrm{HS}\end{array}$} \\
\hline & III MBBS & 110 & 1.27 & 0.676 & $1(1-1)$ & 25.45 & & & \\
\hline \multirow{2}{*}{ Screening } & IV MBBS & 90 & 0.96 & 0.207 & $1(1-1)$ & 95.56 & 4.44 & 2.23 & \multirow{2}{*}{$\begin{array}{l}0.026 \\
\text { sig }\end{array}$} \\
\hline & III MBBS & 110 & 1.00 & 0.000 & $1(1-1)$ & 100.00 & & & \\
\hline \multirow{2}{*}{$\begin{array}{l}\text { Is vaccine } \\
\text { available }\end{array}$} & IV MBBS & 90 & 0.89 & 0.316 & $1(1-1)$ & 88.89 & 11.11 & \multirow{2}{*}{3.58} & 0.000 \\
\hline & III MBBS & 110 & 1.00 & 0.000 & $1(1-1)$ & 100.00 & & & HS \\
\hline \multirow{2}{*}{ Info } & IV MBBS & 90 & 1.49 & 1.220 & $2(0-3)$ & 37.22 & 10.40 & \multirow{2}{*}{2.57} & 0.010 \\
\hline & III MBBS & 110 & 1.07 & 0.400 & $1(1-1)$ & 26.82 & & & sig \\
\hline \multirow{2}{*}{ Is HPV Std } & IV MBBS & 90 & 0.33 & 0.474 & $0(0-1)$ & 33.33 & 48.48 & \multirow{2}{*}{6.95} & 0.000 \\
\hline & III MBBS & 110 & 0.82 & 0.387 & $1(1-1)$ & 81.82 & & & HS \\
\hline \multirow{2}{*}{$\begin{array}{l}\text { Antibiotics } \\
\text { cure }\end{array}$} & IV MBBS & 90 & 0.44 & 0.500 & $0(0-1)$ & 44.44 & 55.56 & \multirow{2}{*}{9.00} & 0.000 \\
\hline & III MBBS & 110 & 1.00 & 0.000 & $1(1-1)$ & 100.00 & & & HS \\
\hline Age group & IV MBBS & 90 & 0.30 & 0.461 & $0(0-1)$ & 30.00 & 0.91 & \multirow{2}{*}{0.14} & 0.890 \\
\hline Recommended & III MBBS & 110 & 0.31 & 0.464 & $0(0-1)$ & 30.91 & & & NS \\
\hline \multirow{2}{*}{ Route } & IV MBBS & 90 & 0.33 & 0.474 & $0(0-1)$ & 33.33 & 66.67 & \multirow{2}{*}{10.21} & 0.000 \\
\hline & III MBBS & 110 & 1.00 & 0.000 & $1(1-1)$ & 100.00 & & & HS \\
\hline
\end{tabular}

Table 4: Attitude.

\begin{tabular}{|c|c|c|c|c|c|c|c|c|c|}
\hline & Semester & $\mathbf{N}$ & Mean & SD & $\begin{array}{l}\text { Median } \\
\text { (QR) }\end{array}$ & $\begin{array}{l}\text { Level of } \\
\text { attitude (\%) }\end{array}$ & $\begin{array}{l}\text { Gap } \\
(\%)\end{array}$ & $\begin{array}{l}\text { Mann } \\
\text { Whitney Z } \\
\text { value }\end{array}$ & P-value \\
\hline \multirow{2}{*}{ HPV taken? } & IV MBBS & 90 & 0.20 & 0.402 & $0(0-0)$ & 20.00 & 20.00 & \multirow{2}{*}{4.90} & 0.000 \\
\hline & III MBBS & 110 & 0.00 & 0.000 & $0(0-0)$ & 0.00 & & & HS \\
\hline \multirow{2}{*}{$\begin{array}{l}\text { If no, would } \\
\text { you? }\end{array}$} & IV MBBS & 90 & 0.61 & 0.490 & $1(0-1)$ & 61.11 & 35.66 & \multirow{2}{*}{5.08} & 0.000 \\
\hline & III MBBS & 110 & 0.25 & 0.438 & $0(0-1)$ & 25.45 & & & HS \\
\hline \multirow{2}{*}{$\begin{array}{l}\text { Why not } \\
\text { taken }\end{array}$} & IV MBBS & 90 & 1.58 & 1.151 & $2(0-2)$ & 26.30 & 9.63 & \multirow{2}{*}{4.68} & 0.587 \\
\hline & III MBBS & 110 & 1.00 & 0.000 & $1(1-1)$ & 16.67 & & & NS \\
\hline \multirow{2}{*}{ Other std's } & IV MBBS & 90 & 0.71 & 0.456 & $1(0-1)$ & 71.11 & 3.43 & \multirow{2}{*}{0.54} & 0.915 \\
\hline & III MBBS & 110 & 0.75 & 0.438 & $1(0-1)$ & 74.55 & & & NS \\
\hline \multirow{2}{*}{$\begin{array}{l}\text { Enquired by } \\
\text { others }\end{array}$} & IV MBBS & 90 & 0.31 & 0.466 & $0(0-1)$ & 31.11 & 0.71 & \multirow{2}{*}{0.11} & 0.000 \\
\hline & III MBBS & 110 & 0.32 & 0.468 & $0(0-1)$ & 31.82 & & & HS \\
\hline \multirow{2}{*}{$\begin{array}{l}\text { Include in } \\
\text { NIS }\end{array}$} & IV MBBS & 90 & 0.37 & 0.485 & $0(0-1)$ & 36.67 & 42.42 & \multirow{2}{*}{6.08} & 0.000 \\
\hline & III MBBS & 110 & 0.79 & 0.409 & $1(1-1)$ & 79.09 & & & HS \\
\hline \multirow{2}{*}{ Obstacle } & IV MBBS & 90 & 0.37 & 0.485 & $0(0-1)$ & 36.67 & 63.33 & \multirow{2}{*}{9.85} & 0.000 \\
\hline & III MBBS & 110 & 1.00 & 0.000 & $1(1-1)$ & 100.00 & & & HS \\
\hline \multirow{2}{*}{$\begin{array}{l}\text { Men } \\
\text { vaccine }\end{array}$} & IV MBBS & 90 & 0.54 & 0.501 & $1(0-1)$ & 54.44 & 26.26 & \multirow{2}{*}{3.76} & 0.000 \\
\hline & III MBBS & 110 & 0.28 & 0.452 & $0(0-1)$ & 28.18 & & & HS \\
\hline \multirow{2}{*}{$\begin{array}{l}\text { Overall } \\
\text { attitude }\end{array}$} & IV MBBS & 90 & 4.69 & 1.674 & $5(3-6)$ & 36.07 & 2.29 & \multirow{2}{*}{1.83} & 0.067 \\
\hline & III MBBS & 110 & 4.39 & 0.889 & $4(4-5)$ & 33.78 & & & NS \\
\hline
\end{tabular}


Table 5: Practice.

\begin{tabular}{|c|c|c|c|c|c|c|c|c|c|}
\hline & Semester & $\mathbf{N}$ & Mean & SD & $\begin{array}{l}\text { Median } \\
\text { (QR) }\end{array}$ & $\begin{array}{l}\text { Level of } \\
\text { practice } \\
(\%)\end{array}$ & $\begin{array}{l}\text { Gap } \\
(\%)\end{array}$ & $\begin{array}{l}\text { Mann Whitney } \\
\text { z value }\end{array}$ & $\begin{array}{l}P \text { - } \\
\text { value }\end{array}$ \\
\hline \multirow{2}{*}{ Ever offered } & IV MBBS & 90 & 0.30 & 0.461 & $0(0-1)$ & 30.00 & \multirow{2}{*}{21.82} & \multirow{2}{*}{3.99} & 0.000 \\
\hline & III MBBS & 110 & 0.08 & 0.275 & $0(0-0)$ & 8.18 & & & HS \\
\hline \multirow{2}{*}{ Ever advised } & IV MBBS & 90 & 0.28 & 0.450 & $0(0-1)$ & 27.78 & \multirow{2}{*}{12.32} & \multirow{2}{*}{2.12} & 0.034 \\
\hline & III MBBS & 110 & 0.15 & 0.363 & $0(0-0)$ & 15.45 & & & sig \\
\hline \multirow{2}{*}{ Recommend } & IV MBBS & 90 & 0.67 & 0.474 & $1(0-1)$ & 66.67 & \multirow{2}{*}{22.42} & \multirow{2}{*}{3.86} & 0.000 \\
\hline & III MBBS & 110 & 0.89 & 0.313 & $1(1-1)$ & 89.09 & & & HS \\
\hline \multirow{2}{*}{ Screening } & IV MBBS & 90 & 0.42 & 0.497 & $0(0-1)$ & 42.22 & \multirow{2}{*}{40.51} & \multirow{2}{*}{5.94} & 0.000 \\
\hline & III MBBS & 110 & 0.83 & 0.380 & $1(1-1)$ & 82.73 & & & HS \\
\hline \multirow{2}{*}{ Practice } & IV MBBS & 90 & 1.67 & 0.972 & $2(1-2)$ & 41.67 & \multirow{2}{*}{7.20} & \multirow{2}{*}{2.97} & 0.003 \\
\hline & III MBBS & 110 & 1.95 & 0.531 & $2(2-2)$ & 48.86 & & & HS \\
\hline
\end{tabular}

Table 6: Overall knowledge, attitude and practice.

\begin{tabular}{|c|c|c|c|c|c|c|}
\hline & Sex & $\mathbf{N}$ & Mean & SD & $\begin{array}{l}\text { Mann Whitney } \mathrm{z} \\
\text { value }\end{array}$ & P-value \\
\hline \multirow{3}{*}{$\begin{array}{l}\text { Overall } \\
\text { knowledge }\end{array}$} & $\mathrm{F}$ & 112 & 8.05 & 2.23 & \multirow{3}{*}{1.137} & \multirow{3}{*}{$0.256 \mathrm{NS}$} \\
\hline & M & 88 & 8.39 & 2.08 & & \\
\hline & Total & 200 & 8.20 & 2.17 & & \\
\hline \multirow{3}{*}{$\begin{array}{l}\text { Overall } \\
\text { attitude }\end{array}$} & $\mathrm{F}$ & 112 & 4.34 & 1.37 & \multirow{3}{*}{2.622} & \multirow{3}{*}{$0.009 \mathrm{HS}$} \\
\hline & M & 88 & 4.76 & 1.19 & & \\
\hline & Total & 200 & 4.53 & 1.31 & & \\
\hline \multirow{3}{*}{$\begin{array}{l}\text { Overall } \\
\text { practice }\end{array}$} & $\mathrm{F}$ & 112 & 1.92 & 0.71 & \multirow{3}{*}{1.588} & \multirow{3}{*}{$0.112 \mathrm{NS}$} \\
\hline & M & 88 & 1.70 & 0.83 & & \\
\hline & Total & 200 & 1.83 & 0.77 & & \\
\hline
\end{tabular}

Most of the students, $100(50 \%)$ had obtained the information regarding the vaccine from an academic session.60\% of the students knew that human papilloma virus infection was a sexually transmitted disease and majority knew it could not be cured with antibiotics. $70 \%$ of the students knew that the vaccine was to be administered by the intramuscular route. Most of them were not aware regarding the age at which the vaccine was recommended or effective (Table 3).

There were $91 \%$ of the students had not taken the vaccine while $41.5 \%$ would take the vaccine if offered to them. $57 \%$ cited the reason as not having given a thought for not taking the vaccine.

There were $73 \%$ knew the vaccine is not effective against another STD's. Majority of them agreed that the vaccine should be included in the national immunization schedule while lack of awareness was thought to be the major obstacle in the implementation of the same. $40 \%$ were aware about the fact that men need to be vaccinated (Table 4). There were $18 \%$ had been offered the vaccine while $21 \%$ had been advised the same. $65 \%$ felt that screening is important while $79 \%$ were ready to recommend it to others (Table 5).
When the results were statistically analysed, the results were found to be significant for the attitude based on the $\mathrm{P}$-value and Z-score (Table 6).

\section{DISCUSSION}

Majority of the participants were well aware of the preventable nature of cervical cancer and its viral etiology. This was in contrast to a study conducted by Saha A et al, Kolkata which disclosed reduced levels of awareness among graduate and postgraduate students. ${ }^{8}$

Awareness regarding the availability of a vaccine was $96 \%$ which was in contrast to a study done in Belgium by Donders GG et al, in which awareness regarding availability among women attending clinic was $50 \% .^{9}$

A study done in Kolkata among female students reflected low level of knowledge of cervical cancer and its risk factors and only $11 \%$ and $15 \%$ were aware of Pap smear and HPV respectively. ${ }^{10}$

In this study, the most common source of information was an academic session followed by health professionals. In a study done by Joshi A et al, the most 
common source of information was internet followed by an academic session. ${ }^{11}$

Pandey D et al, demonstrated that educational strategies can go a long way in promoting immunization against cervical cancer. $^{7}$

Study done by Naik PR et al, in a rural Indian population in Maharashtra recommended that increasing awareness will motivate symptomatic individuals to seek medical consultation and treatment in the early stages and thus result in better survival. ${ }^{10}$

In this study, majority of them agreed that the vaccine should be included in the National Immunization schedule and most of them thought that lack of awareness was the major obstacle in the implementation of the vaccine in the schedule.

This was in contrast to a study done by Bharadwaj $\mathrm{M}$ et al, in which the major obstacle was thought to be high cost of the vaccine. ${ }^{12}$

Expenses, acceptability, lack of awareness and infrastructure, worries about unknown side effects and social and religious beliefs were found to be the prime roadblocks according to a study by Bhatla $\mathrm{N}$ et al. ${ }^{13}$

Overall awareness and assessment of knowledge and practice among males and females showed no statistically significant difference while males revealed a better attitude towards the vaccine than females in the study.

The strengths of present study included a prospective study design and answers from members of different educational ranks were scrutinized separately in order to decrease the bias of medical teaching. The questionnaire was validated by a clinician as well as by interns and postgraduate students. Awareness and acceptance among males and females were assessed separately.

Present study also had a few limitations namely; this was a questionnaire-based study which could result in bias. The study was conducted in only 1 medical college which might not reflect the overall awareness of all the medical students in India. The study was conducted among medical students. Therefore, all the results cannot be taken as a reflection of the general population.

\section{CONCLUSION}

HPV vaccine for the primary prevention of cervical cancer is a novel concept. Health professionals can play an important role in propagating this strategy. Curriculum in the medical schools must focus on such issues.

Medical students may not be involved in teaching at medical schools but could prove to be vital instruments of knowledge to the society filled with information in this internet era.
Funding: No funding sources

Conflict of interest: None declared

Ethical approval: The study was approved by the Institutional Ethics Committee

\section{REFERENCES}

1. Bruni L, Barrionuevo-Rosas L, Albero G, Aldea M, Serrano B, Valencia S, et al. ICO information centre on HPV and cancer (HPV Information Centre). Human papillomavirus and related diseases in the world. Summary Report. 2015:12-23. Accessed at: https://www.hpvcentre.net/statistics/reports/XWX.pd f.

2. Parkin DM, Bray F, Ferlay J, Pisani P. Global cancer statistics, 2002. CA: A Cancer J Clinic. 2005;55(2):74-108.

3. WHO/ICO information centre on HPV and cervical cancer (HPV information Centre). Summary report on HPV and cervical cancer statistics in India, 2007. Available at: http://www.who.int/hpvcentre. Assessed 2014 July 29.

4. Stridh S, Hammar S. Knowledge of Human papillomavirus (HPV) and attitudes towards HPVvaccine among Thai female university students. 2013:1-28.

5. Nigam A, Saxena P, Acharya AS, Mishra A, Batra S. HPV vaccination in India: critical appraisal. ISRN Obstet Gynecol. 2014;2014.

6. Challa N, Madras V, Challa N. Awareness and attitude regarding human papilloma virus and its vaccine among medical students in a medical school in India. Int J Res Med Sci. 2014; 2(4):1607-11.

7. Pandey D, Vanya V, Bhagat S, Binu VS, Shetty J. Awareness and attitude towards human papillomavirus (HPV) vaccine among medical students in a premier medical school in India. PloS One. 2012;7(7):e40619.

8. Saha A, Chaudhury AN, Bhowmik P, Chatterjee R. Awareness of cervical cancer among female students of premier colleges in Kolkata, India. Asian Pac J Cancer Prev. 2010;11(4):1085-90.

9. Donders GG, Gabrovska M, Bellen G, Van Keirsbilck J, Van Den Bosch T, Riphagen I, et al. Knowledge of cervix cancer, human papilloma virus (HPV) and HPV vaccination at the moment of introduction of the vaccine in women in Belgium. Archives Gynecol Obstet. 2008;277(4):291-8.

10. Naik PR, Nagaraj K, Nirgude AS. Awareness of cervical cancer and effectiveness of educational intervention programme among nursing students in a rural area of Andhra Pradesh. Healthl. 2012;3(2):415.

11. Joshi A, Bhagat S, Patil K, Gambre R, Patel S. To evaluate the awareness about human papilloma virus(HPV)vaccine in the prevention of cervical cancer amongst the medical students : A KAP study. Int J of Allied Med Sci and Clin Res.2014;2(4):35866. 
12. Bharadwaj M, Hussain S, Nasare V, Das BC. HPV \& HPV vaccination: issues in developing countries. Indian J Med Res. 2009;130(3):327.
13. Bhatla N, Joseph E. Cervical cancer prevention \& the role of human papillomavirus vaccines in India. Indian J Med Res. 2009;130(3):334.

Cite this article as: Shetty TS, Kamath P.

Assessment of awareness regarding human papilloma virus vaccine among medical students: a knowledge attitude and practice study. Int J Reprod Contracept Obstet Gynecol 2019;8:2044-9. 